Article

\title{
EU “Mobility" Partnerships: An Initial Assessment of Implementation Dynamics
}

\author{
Natasja Reslow \\ Department of International and European Law, Maastricht University, 6211 LK Maastricht, The Netherlands; \\ E-Mail: n.reslow@maastrichtuniversity.nl
}

Submitted: 17 July 2015 | In Revised Form: 10 September 2015 | Accepted: 17 September 2015 |

Published: 28 September 2015

\begin{abstract}
Cooperation with non-EU countries is a central migration policy priority for the EU, and since 2008 eight Mobility Partnerships have been signed. Given the importance attached to this policy area, it is essential that policy-makers understand how EU external migration policy works in practice. However, the literature on the implementation of EU external migration policy is very limited. This article addresses this deficit, by conducting a conceptual assessment of implementation dynamics in the Mobility Partnerships. At this stage in the implementation process, it is not yet possible to assess whether the Mobility Partnerships have contributed to mobility, which is their stated aim. Instead, the literature on implementation is applied in a "backward" fashion, starting with the implementation dynamics at play. The article concludes that standard analytical frameworks for assessing implementation processes will need to be adapted for "new" policy tools featuring elements of flexibility or voluntary participation, in order to accurately capture implementation processes. Future research should adopt a critical, human rights-centred approach to the issue of implementation of EU external migration policy.
\end{abstract}

\section{Keywords}

European Union; implementation; migration policy; mobility partnerships

\section{Issue}

This article is part of a regular issue of Politics and Governance, edited by Professor Andrej J. Zwitter (University of Groningen, The Netherlands) and Professor Amelia Hadfield (Canterbury Christ Church University, UK).

(C) 2015 by the author; licensee Cogitatio (Lisbon, Portugal). This article is licensed under a Creative Commons Attribution 4.0 International License (CC BY).

\section{Introduction}

The year 2015 has been a powerful reminder that migrants will take desperate and extraordinary measures to try to reach Europe. In light of the tragic deaths of thousands of migrants in the Mediterranean in early 2015, the European Commission restated the argument that it has made since the early 2000s: one of the key factors for the EU to achieve its migration policy objectives is cooperation with non-EU countries on migration issues (Commission, 2015a, p. 5). To facilitate such cooperation, policy instruments have been created and brought together under the Global Approach to Migration and Mobility (Commission, 2011), and project funding has been made available under successive
EU funding instruments. This has spawned a sizeable literature on EU external migration policy, with scholars examining policy content and policy-making dynamics (e.g. Boswell, 2003; Coleman, 2009; Weinar, 2011). And yet at the same time the literature on implementation of EU external migration policy has remained extremely limited (Wunderlich, 2013a; 2013b; 2012). This is puzzling, and unsatisfactory. Implementation research matters because "putting a piece of legislation or a government programme into practice does not happen automatically, nor is it a purely technical or apolitical affair" (Treib, 2006, p. 5). Implementation research in EU external migration policy matters because the policy area is so salient, and it is therefore important for policymakers to understand how this policy works in practice. 
This article represents a first step in this direction, by providing an initial conceptual assessment of implementation dynamics in the EU's Mobility Partnerships and advancing a future research agenda. The Mobility Partnerships are selected as the object of study because they are the "main strategic, comprehensive and longterm cooperation framework for migration management with third countries" (Council, 2009, p. 61).

Section 2 introduces the Mobility Partnership instrument and argues that a definitive assessment of policy success/failure, in terms of goal realisation, is premature. Instead, the article focuses on implementation dynamics, in order to discern what we might expect from the process of implementing Mobility Partnerships. Section 3 develops a comprehensive analytical framework based on the public policy literature on implementation, and section 4 explains the methodology underlying the article. The analytical framework is applied in section 5 . The conclusion argues that frameworks for assessing implementation will need to be adapted when used for studying "new" policy tools, and that future research on implementation of EU external migration policy should adopt a critical, human rights-centred approach.

\section{The "Mobility" Partnerships}

The concept of Mobility Partnerships was introduced by the European Commission in 2007 (Commission, 2007). The central idea is that legal migration opportunities will be offered to non-EU countries in return for their cooperation on preventing irregular migration; in practice, this has come to mean that Mobility Partnerships include the signature of both readmission and visa facilitation agreements (Commission, 2011, p. 11). This "quid pro quo" is significant, and the fact that the communication setting out the Mobility Partnership concept also addresses circular migration seems to emphasise the centrality of "mobility" for this policy instrument. To date, Mobility Partnerships have been signed with Moldova (2008), Cape Verde (2008), Georgia (2009), Armenia (2011), Morocco (2013), Azerbaijan (2013), Tunisia (2014) and Jordan (2014).

Mobility Partnerships are signed as political declarations, and appended to this declaration is a list of projects for implementation; projects may be proposed by any of the parties to a Mobility Partnership (the Commission, the non-EU country, or participating member states), but in reality most projects have been carried out by member states (Reslow, 2013, p. 138). A Mobility Partnership is best understood as an "umbrella", bringing together the various individual projects. Participation by member states is voluntary, which has led to varied patterns of opting in and out by the different member states, ranging from France (which participates in all partnerships) to Austria, Croatia, Finland, Ireland and Malta (which do not participate in any partnerships so far). All other member states are located somewhere between these extremes, participating in some, but not all, partnerships.

Once a Mobility Partnership has been negotiated and signed, it is implemented through the implementation of the projects proposed. Implementation is monitored at the EU level through a Mobility Partnership task force, and in the non-EU country through a cooperation platform. A Mobility Partnership task force consists of representatives of the Commission and participating member states (Lavenex \& Stucky, 2011, p. 134). The Commission plays a key role by organising meetings and updating the "scoreboard" - a document produced for each individual Mobility Partnership which shows all the projects being implemented and their state of play. The scoreboard for the Mobility Partnership with Moldova is available online (Ministry of Foreign Affairs and European Integration of the Republic of Moldova, 2015), but the other scoreboards are not publically available. On the ground, member states' embassies, EU delegations and non-EU countries' authorities meet in the framework of cooperation platforms to monitor implementation (Commission, 2009a, pp. 5-6). International organisations and NGOs also play a role in the implementation of Mobility Partnerships: the International Organisation for Migration (IOM), for example, has supported the implementation of the development-related components of the Mobility Partnership with Moldova, and both IOM and the International Centre for Migration Policy Development (ICMPD) implement the visa liberalisation action plan in Georgia (Commission, 2014a, p. 3).

The literature on the implementation of EU external migration policy is extremely limited. Initial academic assessments of the Mobility Partnerships have focused on the decision-making process. Member states "wrangle" amongst themselves to ensure that EU policy favours non-EU countries with which they have a special relationship (Parkes, 2009, p. 343). At the same time, they maintain strict control over the form and content of the Mobility Partnerships, thus severely limiting the Commission's room for manoeuvre (Reslow, 2013, p. 229). The exclusion of the European Parliament from the policy-making process has "marginalised any sort of democratic accountability" of this policy instrument (Carrera \& Hernández i Sagrera, 2011, p. 106). Mobility Partnerships can also be considered "insecurity partnerships" because "they undermine the coherence of EU policy on labour immigration and increase the vulnerability of third country workers' human rights in Europe" (p. 97).

Despite their name and the centrality of the idea of mobility as put forward by the Commission (see above), several authors argue that labour mobility schemes have been lacking in the Mobility Partnerships concluded to date (Carrera \& Hernández i Sagrera, 2011; Lavenex \& Stucky, 2011; Parkes, 2009; Reslow, 
2013). These judgements are based on a reading of the Mobility Partnership texts only, and the actual status of mobility in the outcomes of the Mobility Partnerships is uncertain: due to their non-binding nature, full implementation of the proposed projects on mobility cannot be guaranteed (Carrera \& Hernández i Sagrera, 2011, p. 110). On the other hand, new projects on mobility may be added later, that were not originally foreseen.

Ideally an assessment of the process of implementation would be based on the scoreboard for each Mobility Partnership. However, these are not made publically available, so it is difficult to assess the state and progress of implementation. An alternative option is to judge the outcome of Mobility Partnerships in terms of their contribution to mobility, based on the (at least nominal) importance attached to this concept in the original Commission communication, and the rather sceptical initial assessments by scholars. Figure 1 below shows the number of first residence permits issued to citizens of Mobility Partnership countries, and Figure 2 shows the number of short-stay visas issued to citizens of Mobility Partnership countries. From Figure 1 it is clear that none of the Mobility Partnership countries has seen a consistent and significant increase in the number of residence permits being issued. This implies that Mobility Partnerships are actually not contributing to mobility, although other factors (particularly economic) may also affect mobility entirely separately of the Mobility Partnerships. The data on which Figure 2 is based is only available for 2010-2013; however, visa facilitation agreements are usually agreed after the Mobility Partnerships have been signed, meaning ratification and implementation are on-going or at an early stage. ${ }^{1}$

It is therefore not possible to definitively determine the contribution of Mobility Partnerships to mobility: mobility is affected by numerous other factors; and the implementation of important instruments, such as visa facilitation agreements, are still at an early stage. Definitive assessments of implementation success/failure may take years because of the data and evidence required to make such an assessment (Ripley \& Franklin, 1982 , p. 203). This article will therefore apply the literature on implementation in a "backward" fashion: instead of beginning from an observed successful/failed policy implementation and tracing this back to the implementation dynamics, the article conducts a conceptual analysis of the implementation dynamics in order to determine what we can expect in the future from the implementation of the Mobility Partnerships. As this approach is ambivalent regarding the final outcome of implementation, it avoids the accusation commonly levelled at implementation scholars that they focus too much on policy failures (DeLeon, 1999, p. 329). The following section develops an analytical framework based on the public policy literature on implementation.

\footnotetext{
${ }^{1}$ The visa facilitation agreements with Armenia and Azerbaijan entered into force in 2014, and the visa facilitation agreement with Cape Verde has still to be ratified.
}

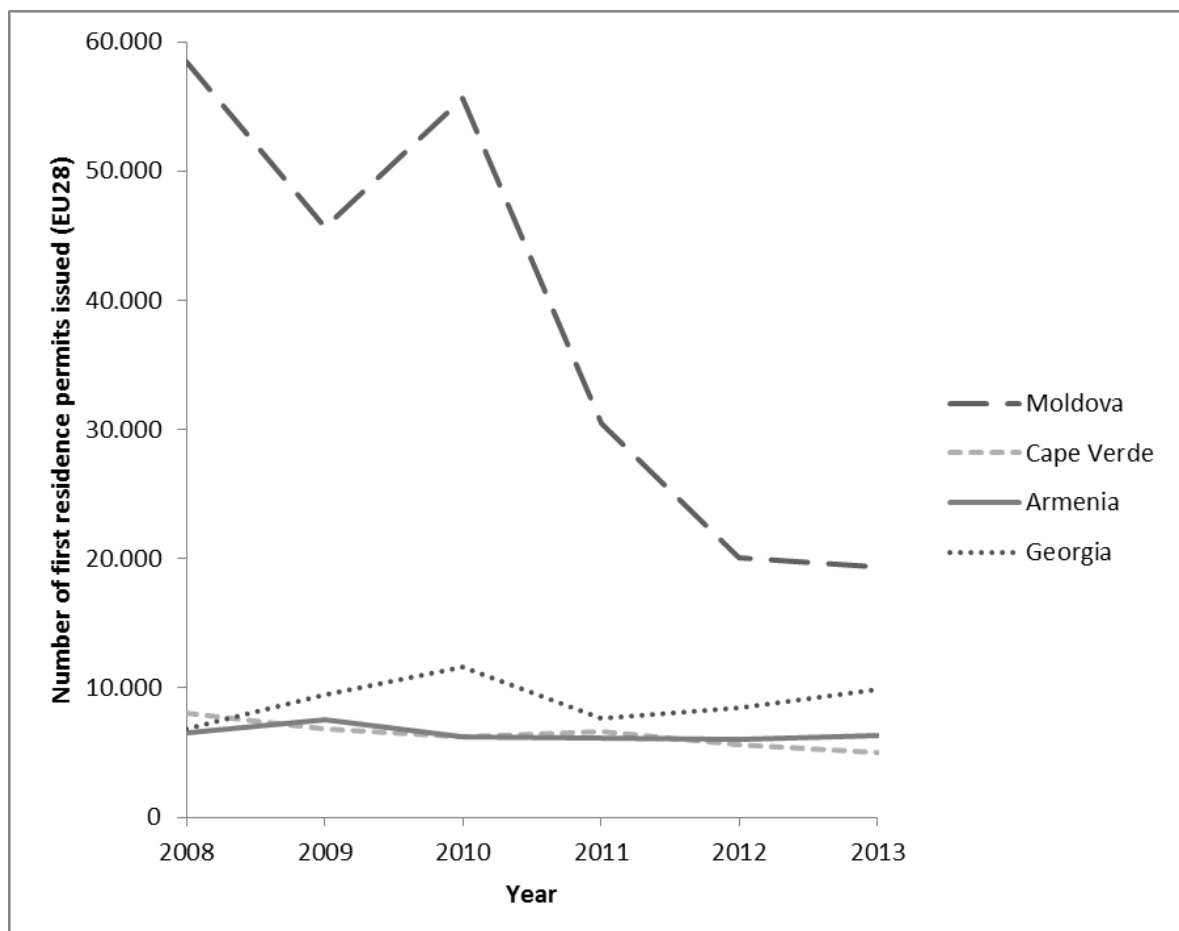

Figure 1. Number of residence permits issued by the EU 28 member states to citizens of Mobility Partnership countries (source: Eurostat). The data concerns residence permits issued for more than 3 months, for all purposes. Eurostat data is currently only available up to 2013; Morocco, Azerbaijan, Tunisia and Jordan are therefore not included, as their Mobility Partnerships were agreed in 2013 and 2014. 


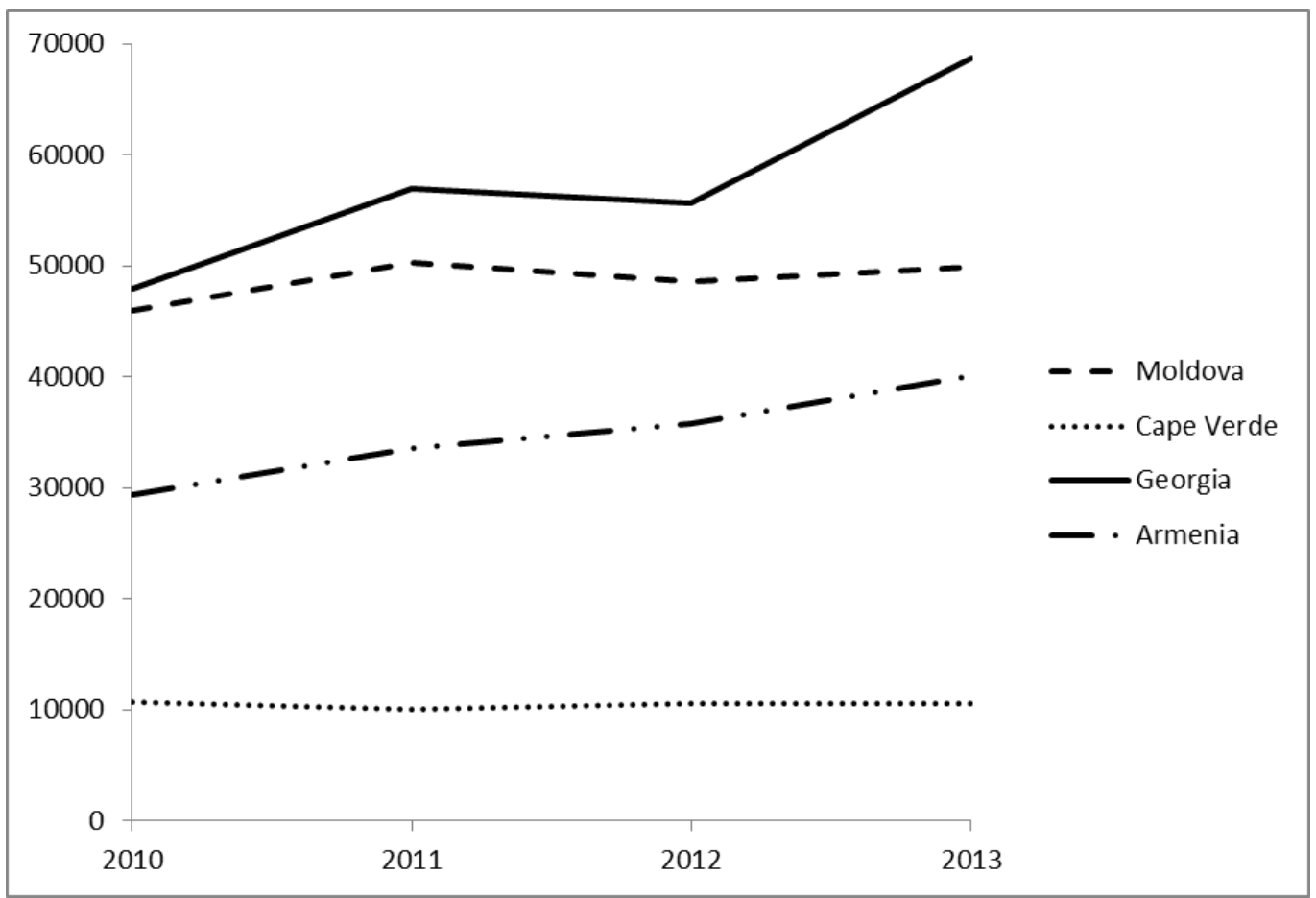

Figure 2. Number of short-stay visas issued to citizens of Mobility Partnership countries (source: Commission, http://ec.europa.eu/dgs/home-affairs/what-we-do/policies/borders-and-visas/visa-policy/index_en.htm; author's own calculations). The data does not include the UK, Ireland or Croatia; data for Romania, Bulgaria and Cyprus is patchy; and the data concerns visas issued by location of member states' embassies, not according to citizenship of the person receiving the visa.

\section{Defining and Assessing Implementation}

It is important to firstly define what is meant by implementation. This is especially so given that some authors writing on EU external migration policy claim to analyse "implementation" whilst actually studying decision-making or policy-making. Wunderlich (2012, p. 1423), for instance, examines why Morocco and Ukraine "have agreed to co-operation on illegal migration", and highlights the concerns of Moroccan and Ukrainian actors concerning migration flows and the requirements of an EU readmission agreement. His analysis therefore concerns broader processes motivating these governments' decisions and relationship with the EU, but not how the implementation of specific projects is functioning. It may be difficult to draw a firm distinction between policy-making and policy implementation, as implementation processes feed into policy formation in an iterative process of feedback and evaluation (Hill \& Hupe, 2002, p. 139; Nakamura, 1987). Nevertheless, this article differentiates between the process leading up to the signature of individual Mobility Partnerships (decision-making) and everything that happens afterwards (implementation).

The literature on the implementation of EU external migration policy to date is very limited. Wunderlich has adopted three different analytical approaches: following the work of Matland (1995) and focussing on the role of conflict and policy ambiguity in the imple- mentation process (2013a); focussing on coherence between the objectives of different policy components (2013b); and following an organisational perspective which holds that implementation dynamics depend on the perception of the policy problem, the macropolitical context, and organisational factors such as administrative capacity and overlap between existing organisational structures and policy objectives (2012). This article develops a comprehensive framework for assessing implementation dynamics, based on an extensive review of the public policy literature on implementation. It therefore brings together these and other factors for a broader view of implementation.

It is necessary to differentiate "implementation" from the notions of "impact" or "policy effectiveness". "Impact" refers to the consequences of a policy decision (i.e. "what happened") and 'implementation' refers to the dynamics and factors which explain programme performance (i.e. "why did it happen in this way"). Policy impact is therefore the extent to which policy objectives were achieved, and implementation studies examine the factors contributing to this realisation/non-realisation of policy objectives (Van Meter \& Van Horn, 1975, p. 448). This article focuses on implementation dynamics.

The analytical framework in this article is based on the public policy literature, because the literature on EU compliance suffers from the problem that it has focussed extensively on the implementation of EU legis- 
lation (e.g. Bursens, 2002; Hartlapp, 2007; Skjærseth \& Wettestad, 2008). This is problematic for EU external migration policy for two main reasons: firstly, EU external migration policy is not based on legislation, and little of it is legally-binding (apart from readmission and visa facilitation agreements, which are international agreements). It is thus futile to look for evidence of member states adopting supportive national legislation. Secondly, focusing on EU legislation reduces implementation to an internal EU affair and a matter of the dynamics at play between the EU institutions and the member states, and within the member states' national administrations. Implementation of EU external migration policy, however, relies on non-EU countries, and their role must also be considered in order to reach a comprehensive understanding of implementation processes (Wunderlich, 2013a, p. 409).

The public policy literature on implementation has highlighted a number of factors required for successful policy implementation. These factors draw on both the top-down perspective (those factors that central policy-makers can control) and the bottom-up perspective (those factors outside the control of central policymakers). Although the article does not engage with the "top-down versus bottom-up" debate within implementation research (see e.g. Matland, 1995), it draws mainly on the work of the scholars writing from the top-down perspective. This choice is made because the focus here is on a particular policy instrument (cf. Sabatier, 1986, p. 37).

Successful policy implementation depends firstly on the tractability of the problem being addressed: there must be a clear understanding of the link between the problem and the solutions which can address this problem, and existing practices causing the problem should not be diverse (Goggin, Bowman, Lester \& O'Toole, 1990, p. 35; Sabatier \& Mazmanian, 1980, pp. 541-544; Wunderlich, 2012, p. 1418).

Secondly, successful policy implementation is more likely if the new policy does not deviate substantially from previous policies: "incremental changes are more likely to engender a positive response than will drastic ones" (cf. Sabatier \& Mazmanian, 1980, p. 543; Skjærseth \& Wettestad, 2008, p. 277; Wunderlich, 2012, p. 1419; Van Meter \& Van Horn, 1975, p. 458). Knill and Lenschow (2000, p. 32) refer to a "bounded space for innovation", which is the fine line between requiring "something, but not too much".

Thirdly, policy objectives which are clear and are ranked in terms of their relative importance are more likely to be successfully implemented (Goggin, Bowman, Lester \& O'Toole, 1990, p. 35; Sabatier \& Mazmanian, 1980, p. 545; Wunderlich, 2012). This is complicated for EU external migration policy because the various actors involved in implementation are likely to have different objectives and priorities (Wunderlich, 2013b, p. 28).
Fourthly, implementing agencies must have financial and organisational resources (meaning an adequate number of skilled staff) available to ensure successful implementation (Sabatier \& Mazmanian, 1980, p. 545; Van Meter \& Van Horn, 1975, p. 471).

Fifthly, successful implementation is more likely if implementing agencies are integrated in a single hierarchical structure (Sabatier \& Mazmanian, 1980, p. 546; Van Meter \& Van Horn, 1975, pp. 466-467). In political systems where multiple actors are in charge of implementing a single policy, "command from the centre, control by the centre, and obedience by those commanded and controlled" cannot be taken for granted (Ripley \& Franklin, 1982, p. 188). This is not surprising given that these political systems (like the United States federal structure and the European Union) were designed to limit the authority of central government (Hill \& Hupe, 2002, p. 72). The degree of hierarchical integration amongst implementing agencies depends on the number of actors who have the opportunity to prevent policy objectives being achieved, and on the availability of inducements and sanctions to ensure that actors act in accordance with policy objectives (Sabatier \& Mazmanian, 1980, p. 546). These inducements/sanctions can take various forms: the threat of punishment for non-compliance; the transfer of knowledge and resources to actors facing difficulties complying; and persuading actors to change their underlying norms and values (Hartlapp, 2007). Sanctions and punishment are most effective when there is a direct hierarchical relationship between the two sets of actors concerned (Matland, 1995, p. 164).

Sixthly, the interests and motives of implementing officials affect the implementation process (Hill \& Hupe, 2002, p. 152; Wunderlich, 2012, p. 1420). Implementation is more likely to be successful if implementing officials agree with the policy objectives. This can be ensured by their inclusion in the policy-making process (Sabatier \& Mazmanian, 1980, p. 547; Van Meter \& Van Horn, 1975, p. 459).

Finally, the context within which a policy is implemented matters. Economic, social and political conditions can all affect the public and political support for a policy. Changing socio-economic conditions can make the problem being addressed by the policy relatively less important, and thus decrease public and political support. Media attention affects the perception of importance of an issue; policies which receive sustained media coverage are more likely to be successfully implemented. Public opinion influences the political agenda, and so a policy which has high support amongst the public and is perceived as being highly salient is more likely to be successfully implemented. Interest groups and elites mobilising in favour of a policy also affect implementation (Goggin, Bowman, Lester \& O'Toole, 1990, p. 39; Sabatier \& Mazmanian, 1980, pp. 548-550; Van Meter \& Van Horn, 1975, pp. 471-472). 
Section 5 applies the framework outlined above in analysing implementation dynamics in EU Mobility Partnerships. The following section first explains the methodology underlying the article.

\section{Methodology}

Table 1 summarises the analytical framework by showing how each of the factors identified will be applied in the analysis in section 5 . Given that this article represents an initial conceptual assessment of implementation dynamics in the Mobility Partnerships, the analysis is based mainly on secondary literature. It also relies on documents by the Commission and Council, particularly the 2007 Commission communication on Mobility Partnerships, the 2009 Commission evaluation of the Mobility Partnerships, and the texts of the individual partnerships. These are the main policy documents relating to the Mobility Partnerships which are publically available.

Table 1. Operationalisation of the analytical framework.

\begin{tabular}{ll}
\hline $\begin{array}{l}\text { Factor for successful } \\
\text { implementation }\end{array}$ & Definition \\
\hline Tractability of the problem & $\begin{array}{l}\text { Clear understanding of the } \\
\text { link between the problem } \\
\text { and the solutions } \\
\text { Existing practices causing the } \\
\text { problem are not diverse }\end{array}$ \\
Nature of change required & $\begin{array}{l}\text { Policy does not deviate } \\
\text { substantially from previous } \\
\text { policies }\end{array}$ \\
Clarity of policy objectives & $\begin{array}{l}\text { Policy objectives are clear } \\
\text { Policy objectives are ranked } \\
\text { in terms of relative } \\
\text { importance }\end{array}$
\end{tabular}

Financial and organisational Adequate financial means for resources for implementation

Relationship between implementing agencies

Disposition of implementing officials implementation Adequate number of skilled staff for implementation

One actor can force another to act in a certain way, through sanctions/inducements

Implementing officials agree with policy objectives Implementing officials have been included in the policymaking process

Implementation context
Socio-economic conditions are favourable Sustained media coverage of the policy

Public opinion is favourable Interest groups and elites mobilise in favour of the policy

\section{Implementation Dynamics in EU Mobility Partnerships}

\subsection{Tractability of the Problem}

An analysis of EU policy documents suggests that, at least within the EU, there is a clear understanding that the problem to be addressed is the management of migration flows to the EU, and the solution to this problem is cooperation with non-EU countries. Since the early 2000s, EU policy documents argue that cooperation with non-EU countries is the key to preventing irregular migration to the EU (e.g. Commission, 2001), and that such cooperation needs to be incentivised, for instance by linking the signature of readmission agreements to visa facilitation agreements (Council, 2005). However, it is not clear that non-EU countries share this view. Cooperating with the EU on the prevention of irregular migration may be coupled with high social, political and economic costs (Coleman, 2009; Ellermann, 2008; Weinar, 2011). For non-EU countries the issue is not one of preventing irregular emigration, but rather about securing better access for their citizens to EU territory.

Existing practices by member states in the area of external migration policy are diverse. France, for instance, has signed agreements with non-EU countries on the management of migration flows, which are very similar to Mobility Partnerships in that they encompass legal migration, visas, readmission, police cooperation, reintegration, and development (European Migration Network, 2010a, p. 45). The Austrian government, on the other hand, implements assisted voluntary return programmes and information campaigns about the dangers of irregular migration (European Migration Network, 2010b), but does not facilitate temporary or circular migration to Austria due to the experiences with the guest-worker schemes in the 1960s and 1970s. Whilst the literature on implementation suggests that such diversity will negatively affect policy implementation, the voluntary nature of the Mobility Partnerships mitigate this: member states whose existing policy practices do not match well with the Mobility Partnership approach can simply choose not to participate, as is the case with Austria (Reslow, 2013).

\subsection{Nature of Change Required}

Mobility Partnerships sit at the crossroads of migration policy and foreign policy. These two policy areas are politically sensitive and important to state sovereignty. Control over entry into a country's territory "is often seen as one of the last bastions of national sovereignty" (Lavenex, 2011, p. 2). EU migration policy is filled with caveats, particularly references to member states' continued competence on entry and residence of thirdcountry nationals (see e.g. article $1(b)$ of the Single 
Permit Directive). Foreign policy is at the core of national sovereignty, and although member states conduct a significant amount of their foreign policy objectives through the EU context, they maintain their own distinct priorities, preferences, and privileged relationships with individual non-EU countries.

A policy instrument requiring any change in this nexus between migration policy and foreign policy might then be expected to engender opposition. The overall objective of the Mobility Partnerships to enhance migration opportunities for citizens of the nonEU country concerned certainly does not seem to fit well with the tendency by most member states towards restrictive immigration policies. However, Mobility Partnerships do not in reality require all that much change by member states, given their voluntary nature. Member states are free in their choice of which projects to propose; indeed, despite the overall aim of the Mobility Partnerships to combine cooperation on irregular and legal migration, the Mobility Partnerships with Moldova, Cape Verde and Georgia did not include many projects aiming to create new channels of migration (Reslow, 2013, p. 138).

A separate issue concerns the nature of change required by the other partner in the implementation process, namely the non-EU country concerned. This will depend on the particular non-EU country. The most onerous requirement associated with a Mobility Partnership is the signature of a readmission agreement. However, with some non-EU countries (like Moldova) a readmission agreement already exists before the signature of a Mobility Partnership. The change required for such a country will be less than for a country (like Morocco) that has been in arduous, drawn-out negotiations with the EU over a readmission agreement for several years.

\subsection{Clarity of Policy Objectives}

Although the overall objective of the Mobility Partnerships-better legal migration opportunities for non-EU countries that commit themselves to cooperating with the $\mathrm{EU}$ on preventing irregular migration-is relatively unambiguous, the Commission communication lists many possible types of projects that could fall under a Mobility Partnership (see Commission, 2007, pp. 4-8). The communication is also rather vague regarding the legal nature of Mobility Partnerships, stating only that they "will necessarily have a complex legal nature" ( $p$. $3)$. It does not rank the different types of projects in terms of their relative importance, and does not assign more weight to either the commitments by non-EU countries on irregular migration or the commitments by member states on legal migration.

The clarity of policy objectives is further compromised by the preamble to each individual Mobility Partnership, which states the aims of cooperation. A
Mobility Partnership is always linked to the existing frameworks of cooperation, and this differs amongst non-EU countries. In other words, the framing of a Mobility Partnership is not fixed but depends on the particular non-EU country concerned. In addition, the first Mobility Partnerships did not include asylum as one of the pillars of cooperation (e.g. Council, 2008), but the later Mobility Partnerships do (e.g. Council, 2013). Overall then, the specific policy objectives are too numerous and potentially competing to be defined as "clear". When the sub-goals of a policy are so numerous and varied, disagreement over implementation is likely to arise between actors with different training (Matland, 1995, p. 169). In the case of the Mobility Partnerships, civil servants in interior/justice ministries are likely to have different proposals for implementation than civil servants in foreign ministries (see e.g. Pawlak, 2009, p. 37).

\subsection{Financial and Organisational Resources Available for Implementation}

A consideration of the financial and organisational resources available for implementation must take place across three levels: the EU, the member states, and the non-EU country concerned. For the EU level, answers need to be sought across a number of institutional settings. In terms of financial resources, the 2014 work programme of the EU's Asylum, Migration and Integration Fund set aside $€ 3$ million specifically to support the implementation of the Mobility Partnerships, focussing on Azerbaijan, Morocco, Jordan and Tunisia (Commission, 2014b, p. 11). However, funding for the projects carried out within Mobility Partnerships can also come from one of the frameworks for cooperation with the partner countries concerned, such as the European Neighbourhood Instrument or the EU's development cooperation budget. In terms of organisational resources, DG Migration and Home Affairs plays the central role. The Commission's organisational capacity on migration has certainly increased: from only a small task force working on justice and home affairs matters prior to 1999 (Lavenex, 2009, p. 259), to the creation of DG JLS, and the later separation into what is now DG Migration and Home Affairs, with a staff of 275 on 1 January 2014 and 295 on 1 February 2015 (Commission, 2015b; 2014c). The European External Action Service has also become an important actor in EU external migration policy, particularly because it controls the EU delegations which play an important role in monitoring implementation of Mobility Partnerships. However, EU officials on the ground "are not necessarily initially well-informed and equipped to follow-up on intensified and increased activities on migration in the partner country or to ensure their articulation with already existing activities in that field" (Commission, 2009a, p. 6).

Member states and non-EU countries have differ- 
ent resources available for implementing Mobility Partnerships, and it is difficult to draw universal conclusions about these capacities. In small member states with small administrations, one individual civil servant might be responsible for a number of tasks which in a larger member state would be shared between several people (cf. Engelmann, 2015, p. 211). In newer member states, where migration as a policy area is a relatively new phenomenon, experience and expertise might be lacking (p. 129). Several member states participating in Mobility Partnerships face the problem that they are not represented locally by an embassy in the country concerned (Lavenex \& Stucky, 2011, p. 136). However, it is not the case that only large/old member states are choosing to join the Mobility Partnerships; for example, in the Mobility Partnership with Azerbaijan, participating member states include Bulgaria, the Czech Republic, Lithuania, Poland, Slovenia and Slovakia (Council, 2013). Future research should establish whether there is a causal link between member states' organisational capacity and implementation of the Mobility Partnerships.

It is equally difficult to come to a general conclusion regarding non-EU countries. Empirical research has shown that both Cape Verde (which signed a Mobility Partnership) and Senegal (which refused to sign a Mobility Partnership) have limited organisational capacity in the area of migration: competence is shared between several ministries, with little inter-ministerial communication or coordination. It has been shown that this did not affect these countries' preferences on whether or not to participate in the Mobility Partnerships (Reslow, 2012); however, the literature on implementation suggests this limited organisational capacity will negatively affect implementation.

\subsection{Relationship between Implementing Agencies}

Three sets of actors are involved in making and implementing EU external migration policy: the EU, the member states, and the non-EU countries. However, these actors are not integrated in a single hierarchical structure. The relationship between the EU institutions and the EU member states is determined by the nature of the policy area: competence for both migration policy and foreign policy is shared between the EU and the member states. The Mobility Partnerships are not legally binding international agreements, but rather political declarations (Commission, 2009a, p. 4). This has meant that the Commission has been unable to force member states to implement the partnerships in a certain way. For instance, Commission officials favour multilateral projects over bilateral initiatives, and the funding allocated to Mobility Partnerships under the thematic programme for cooperation with non-EU countries in the areas of migration and asylum was partly conditional on partnership between member states (Commission, 2009b, p. 10). This inducement has not been sufficient, as the Mobility Partnerships are dominated by bilateral projects (Reslow, 2013, p. 137). In theory, the scoreboards might serve a "naming and shaming" function; however instances of projects being duplicated imply that member states' officials do not pay too close attention to the scoreboards (p. 237).

The relationship between the EU and the non-EU country is more difficult to characterise, and depends on the particular non-EU country concerned. Countries in the EU's immediate neighbourhood with deep ties to the EU through several frameworks (such as the European Neighbourhood Policy) have more of a stake, including financially, in cooperation with the EU (cf. Wunderlich, 2012). By contrast, countries further away with less well-developed relations with the EU or for which cooperation with the EU is not a domestic priority, may be less inclined to participate in the Mobility Partnerships (see e.g. Chou \& Gibert [2012] on the case of Senegal). The implementation of Mobility Partnerships is overseen by local cooperation platforms, bringing together representatives of the government of the non-EU country, member states' embassies, and the EU delegation (Commission, 2009a, p. 6). An examination of the nature of the interactions within these cooperation platforms would increase our understanding of the relationship between the actors in the Mobility Partnerships.

\subsection{Disposition of Implementing Officials}

As indicated above, three sets of actors are involved in implementing the Mobility Partnerships. Their dispositions towards this policy instrument are likely to be very different. As the idea originated in the European Commission, officials in DG Migration and Home Affairs can be expected to view Mobility Partnerships positively. The Commission has long emphasised the need to offer non-EU countries a real incentive in return for their cooperation on preventing irregular migration, and this is what the Mobility Partnerships aim to do. DG Home maintains the scoreboards and has a coordinating role in the implementation of the partnerships. However, the position of the European External Action Service (EEAS) should also be considered, as the EU delegations (which fall under the EEAS) play a key role in the local cooperation platforms that oversee implementation. Boswell (2003) argues that the former DG for Justice, Freedom and Security had very different priorities in relation to external migration policy than did the DGs for external relations and development. The same argument has been made with regard to national administrations: whereas interior ministries are "inward-looking" and might seek to prevent entry to the national territory through the signature of readmission agreements, foreign ministries might view such agreements suspiciously because they spoil good dip- 
lomatic relations (Pawlak, 2009; Van Selm, 2005). The EEAS emphasises the need to see the positive contributions of migration (EEAS, n.d.), but further research is required to uncover officials' true disposition.

The voluntary nature of the Mobility Partnerships, although potentially problematic in some respects (see e.g. section 4.5), may be linked to a positive disposition of implementing officials towards the policy instrument. Member states that participate have voluntarily signed up to do so, and have been included in the policy-making process (see Reslow, 2013). In many cases the projects implemented under Mobility Partnerships are not new; rather member states have rephrased existing initiatives that they would have carried out anyway (pp. 136-137). While this may not be very ambitious (cf. Skjærseth \& Wettestad, 2008), it ensures member states' commitment to these projects. On the other hand, given the initial lack of clarity over the nature and aims of the Mobility Partnerships (see section 4.3 above), it is possible that some member states signed up to participate without fully understanding the consequences of this. Future research should try to establish links between officials' dispositions in the decision-making stage and actual implementation process.

Despite having signed up to the Mobility Partnerships, empirical research has shown that officials in non-EU countries are not necessarily positive about all aspects of this policy instrument. Cape Verdean government officials, for instance, were critical of the pressure put on them to sign the readmission agreement, because it makes them responsible for readmitting migrants who have merely transited through Cape Verde on their way to the EU (Reslow, 2013, pp. 207209). Given that a Mobility Partnership encompasses various types of projects, covering all pillars of the Global Approach to Migration and Mobility, implementation success will likely differ depending on the contents of the projects.

\subsection{Implementation Context}

Economic, social and political conditions can all affect the public and political support for a policy. The Commission communication on Mobility Partnerships makes clear that "mechanisms to facilitate economic migration should be based on the labour needs of interested member states, as assessed by them" (Commission, 2007 , p. 5). The economic crisis in Europe, which took hold just as the first Mobility Partnerships started to be signed, led to many EU member states making immigration policy more restrictive, clamping down on irregular migration, and encouraging return migration (e.g. IOM, 2010; Kuptsch, 2012). In addition, the Commission communication stresses that projects within Mobility Partnerships will respect the legal principle of preference for EU citizens (Commission, 2007, p. 5). The Mobility Partnerships are therefore being implemented in un- favourable circumstances, as these socio-economic conditions are not conducive to the creation of new channels of immigration from non-EU countries.

The Mobility Partnerships link two issues: irregular migration, and legal immigration. There is plenty of media coverage of the problem of irregular migration at Europe's borders, with recent coverage focusing on the fate of migrants who get into trouble in the Mediterranean Sea (see e.g. EUObserver, 2015; The Guardian, 2015). However, legal migration is not mentioned as a solution to this problem. In fact, immigration from outside the EU is often negatively portrayed (see e.g. De Telegraaf, 2010; Jyllands-Posten, 2014), and recently the free movement of EU citizens has even been called into question (e.g. Financial Times, 2013). There has been no media coverage of the Mobility Partnerships in EU member states.

As there has been no media coverage of the Mobility Partnerships and no public communication about this policy instrument by either the Commission or member states' governments, there is no public knowledge of this policy instrument, making it impossible to judge public opinion. Public opinion on irregular migration and legal immigration in general, however, may be a useful proxy measure. It is clear that many Europeans are sceptical about immigration from nonEU countries (e.g. Eurobarometer, 2012, p. 20; Pew Research Center, 2014), and even about free movement of EU citizens (e.g. Migration Watch UK, 2014).

In non-EU countries, public opposition can be expected to the commitments on irregular migration contained in a Mobility Partnership, in particular the requirement to sign a readmission agreement. In Senegal, for example, a readmission agreement that had been agreed with Switzerland was not submitted to the parliament for ratification due to intense public opposition (Ellermann, 2008, p. 168). However, governments armed with the knowledge of negative public opinion can choose not to sign a Mobility Partnership in the first place. The voluntary nature of this policy instrument may thus have a positive effect on the implementation process. Future research should examine the nature of public opinion in non-EU countries that have agreed to a Mobility Partnership.

The mobilisation of interest groups and elites has been shown to be a deciding factor in the decisionmaking process on Mobility Partnerships (Reslow, 2013). However, no general conclusion can be drawn in this respect as elites' positions vary across countries: the French government, for instance, was very committed to getting this new policy instrument off the ground, whilst the Austrian government was concerned that Mobility Partnerships resembled the old guestworker schemes and therefore vigorously opposed them at EU level. Even within a single member state, elites may be up against one another: in the Netherlands (which has joined some of the Mobility Partner- 
ships), the Ministry of Social Affairs and Employment was opposed to participation, but could not prevent it in the face of support from the Ministries of Foreign Affairs and Justice. The question of how the implementation process functions in countries where elites are divided is a highly pertinent one for future research on the Mobility Partnerships.

\section{Conclusion}

This article has provided an initial conceptual assessment of implementation dynamics in EU Mobility Partnerships. Certainly there are potential obstacles to successful implementation, particularly the ambiguous nature of the policy objectives, the lack of hierarchical integration between implementing agencies, and the unfavourable political, economic and social conditions within which implementation is taking place. There are also several unknowns: a future research agenda on implementation of EU external migration policy should focus on the disposition of implementing officials, the nature of public opinion, and the interactions between the actors involved in implementation. The analysis furthermore found that the voluntary nature of the Mobility Partnership instrument may eliminate some of the obstacles identified by the implementation literature, in particular in the member states. Member states choose to participate in a Mobility Partnership and have been included in the policy-making process. They are also free to suggest projects for implementation. Implementing officials might therefore be expected to have a positive disposition towards this policy instrument. This implies that some of the assumptions derived from the public policy literature on implementation may not hold true for "new" policy tools, which incorporate some degree of flexibility or voluntary participation. Scholars studying the implementation of EU external migration policy or other intergovernmental policy areas will need to adapt standard analytical frameworks in order to accurately capture implementation processes.

The analysis showed that implementation may depend on the specific non-EU country concerned, and the type of project being implemented. EU external migration policy includes cooperation on return and readmission, and therefore makes non-EU countries responsible for dealing with migrants. However, international organisations, NGOs and journalists have raised concerns about the treatment of migrants by some countries with which the EU cooperates (see e.g. IRIN, 2015 on the situation in Morocco). The question therefore is whether successful implementation of policy instruments such as the Mobility Partnerships is actually desirable? Future research on implementation of EU external migration policy should take this normative dimension into account by adopting a critical and human rights-centred approach to the issue.

\section{Acknowledgments}

This work was supported by the European Union's Seventh Framework Programme for research, technological development and demonstration under grant agreement no. 612921.

\section{Conflict of Interests}

The author declares no conflict of interests.

\section{References}

Boswell, C. (2003). The "external dimension" of EU immigration and asylum policy. International Affairs, 79(3), 619-638.

Bursens, P. (2002). Why Denmark and Belgium have different implementation records: On transposition laggards and leaders in the EU. Scandinavian Political Studies, 25(2), 173-195.

Carrera, S., \& Hernández i Sagrera, R. (2011). Mobility partnerships. "Insecurity partnerships" for policy coherence and migrant workers' human rights in the EU. In R. Kunz, S. Lavenex, \& M. Panizzon (Eds.), Multilayered migration governance. The promise of partnership (pp. 97-115). London: Routledge.

Chou, M.-H., \& Gibert, M. (2012). The EU-Senegal mobility partnership: From launch to suspension and negotiation failure. Journal of Contemporary European Research, 8(4), 408-427.

Coleman, N. (2009). European readmission policy. Third country interests and refugee rights. Leiden: Martinus Nijhoff.

Commission. (2001). A common policy on illegal immigration (COM [2001] 672). Brussels: European Commission.

Commission. (2007). On circular migration and mobility partnerships between the European Union and third countries (COM [2007] 248). Brussels: European Commission.

Commission. (2009a). Mobility partnerships as a tool of the global approach to migration (SEC [2009] 1240). Brussels: European Commission.

Commission. (2009b). Thematic programme for cooperation with third countries in the areas of migration and asylum. Restricted call for proposals 2009-2010. Guidelines for grant applicants. Retrieved from https://webgate.ec.europa.eu/europeaid/online-ser vices/index.cfm?ADSSChck $=1252051189272 \&$ do $=$ publi.getDoc\&documentld=96699\&pubID $=128764$

Commission. (2011). The global approach to migration and mobility (COM [2011] 743). Brussels: European Commission.

Commission. (2014a). Experts group meeting on the global approach to migration and mobility, 26 February 2014. Retrieved from http://ec.europa.eu/ transparency/regexpert/index.cfm?do=groupDetail. 
groupDetailDoc\&id=15388\&no=1

Commission. (2014b). Annex to the Commission implementing decision concerning the adoption of the work programme for 2014 and the financing for union actions and emergency assistance within the framework of the asylum, migration and integration fund (COM [2014] 5652). Brussels: European Commission.

Commission. (2014c). Human resources key figures card. Staff members. Retrieved from http://ec.europa. eu/civil_service/docs/hr_key_figures_en.pdf

Commission. (2015a). A European agenda on migration (COM [2015] 240). Brussels: European Commission.

Commission. (2015b). Statistical bulletin-Off \& TA. Distribution of active officials and temporary agents by DG and gender (all budgets). Retrieved from http:// ec.europa.eu/civil_service/docs/europa_sp2_bs_cat -sexe_x_dg_en.pdf

Council. (2005). Common approach on visa facilitation (16030/05). Brussels: Council of the European Union.

Council. (2008). Joint declaration on a mobility partnership between the European Union and the Republic of Moldova (9460/08 ADD 1). Brussels: Council of the European Union.

Council. (2009). The Stockholm programme (17024/09). Brussels: Council of the European Union.

Council. (2013). Joint declaration on a mobility partnership between the Republic of Azerbaijan and the European Union and its participating member states (16399/13). Brussels: Council of the European Union.

De Telegraaf. (2010). Nyfer: Immigratie kost 7,2 miljard per jaar. De Telegraaf. Retrieved from http://www. telegraaf.nl/binnenland/20443383/_Immigratie_ko st_jaarlijks_7_miljard_.html

DeLeon, P. (1999). The missing link revisited: Contemporary implementation research. Policy Studies Review, 16(3-4), 311-338.

EEAS (European External Action Service) (n.d). Migration and asylum in external relations. Retrieved from http://eeas.europa.eu/migration/index_en.htm

Ellermann, A. (2008). The limits of unilateral migration control: Deportation and inter-state cooperation. Government and Opposition, 43(2), 168-189.

Engelmann, C. (2015). Common standards via the backdoor. The domestic impact of asylum policy coordination in the European Union (Ph.D. thesis). Maastricht University, Maastricht.

EUObserver. (2015). Lampedusa tragedy: An SOS the EU can no longer ignore. EUObserver. Retrieved from https://euobserver.com/opinion/127698

Eurobarometer. (2012). Special eurobarometer 380. Awareness of home affairs. European Commission. Retrieved from http://ec.europa.eu/public_opinion/ archives/ebs/ebs_380_en.pdf

European Migration Network. (2010a). Political report 2009. Retrieved from http://ec.europa.eu/dgs/ home-affairs/what-we-do/networks/european_mi gration_network/reports/docs/annual-policy/2009/ 09a._france_annual_policy_report_2009_final_versi on_12mar10_en.pdf

European Migration Network (2010b). The organisation of asylum and migration policies in Austria. European Commission. Retrieved from http://ec.europa.eu/ dgs/home-affairs/what-we-do/networks/European _migration_network/reports/docs/emn-studies/mig ration-policies/01._austria_national_report_organi sation_of_asylum_and_migration_policies_final version_2feb10.pdf

Financial Times. (2013). Free movement within Europe needs to be less free. Financial Times. Retrieved from http://www.ft.com/intl/cms/s/0/add36222-56be11e3-ab12-00144feabdc0.html\#axzz3SGywawht

Goggin, M. L., Bowman, A., Lester, J., \& O’Toole, L. (1990). Implementation theory and practice. Toward a third generation. Glenview: Scott, Foresman/Little, Brown Higher Education.

Hartlapp, M. (2007). On enforcement, management and persuasion: Different logics of implementation policy in the EU and the ILO. Journal of Common Market Studies, 45(3), 653-674.

Hill, M., \& Hupe, P. (2002). Implementing public policy: Governance in theory and in practice. London: Sage.

IOM. (2010). Migration and the economic crisis in the European Union: Implications for policy. Retrieved from http://www.labourmigration.eu/research/ report/12-migration-and-the-economic-crisis-implica tions-for-policy-in-the-european-union

IRIN. (2015). Morocco. The forgotten frontline of the migrant crisis. IRIN. Retrieved from http://newirin. irinnews.org/extras/2015/7/28/morocco-the-forgot ten-front-line-of-the-migrant-crisis

Jyllands-Posten. (2014). 5.000 nye ikke-vestlige indvandrere koster 2,1 mia. Jyllands-Posten. Retrieved from http://jyllands-posten.dk/indland/ECE6449723/5.00 0+nye+ikke+vestlige+indvandrere+koster+2,1+mia.

Knill, C., \& Lenschow, A. (2000). On deficient implementation and deficient theories: The need for an institutional perspective in implementation research. In C. Knill \& A. Lenschow (Eds.), Implementing EU environmental policy. New directions and old problems (pp. 9-35). Manchester: Manchester University Press.

Kuptsch, C. (2012). The economic crisis and labour migration policy in European countries. Comparative Population Studies, 37(1-2), 15-32.

Lavenex, S. (2009). Transgovernmentalism in the area of freedom, security and justice. In I. Tömmel \& A. Verdun (Eds.), Innovative governance in the European Union: The politics of multi-level policymaking (pp. 255-271). Boulder: Lynne Rienner.

Lavenex, S. (2011). Venue-shopping in global migration policy: Multileveling EU external governance. Paper presented at the EUSA Twelfth Biennial conference, Boston.

Lavenex, S., \& Stucky, R. (2011). "Partnering” for migra- 
tion in EU external relations. In R. Kunz, S. Lavenex, \& M. Panizzon (Eds.), Multilayered migration governance. The promise of partnership (pp. 116-142). London: Routledge.

Matland, R. E. (1995). Synthesizing the implementation literature: The ambiguity conflict model of policy implementation. Journal of Public Administration Research and Theory, 5(2), 145-174.

Migration Watch UK. (2014). Opinion Poll Results on Immigration. Retrieved from http://www.migration watchuk.org/briefingPaper/document/249

Ministry of Foreign Affairs and European Integration of the Republic of Moldova. (2015). ScoreboardMonitoring tool of the European Union-Republic of Moldova mobility partnership. Retrieved from http://scoreboard.mfa.gov.md

Nakamura, R. T. (1987). The textbook policy process and implementation research. Policy Studies Review, 7(1), 142-154.

Parkes, R. (2009). EU mobility partnerships: A model of policy coordination? European Journal of Migration and Law, 11(4), 327-345.

Pawlak, P. (2009). The external dimension of the area of freedom, security and justice: Hijacker or hostage of cross pillarization. Journal of European Integration, 31(1), 25-44.

Pew Research Center. (2014). Most support limiting immigration. Pew Research Center. Retrieved from http://www.pewglobal.org/2014/05/12/chapter-3most-support-limiting-immigration

Reslow, N. (2012). The role of third countries in EU migration policy: The mobility partnerships. European Journal of Migration and Law, 14(4), 393-415.

Reslow, N. (2013). Partnering for mobility? Three-level games in EU external migration policy (Ph.D. thesis). Maastricht University, Maastricht.

Ripley, R. B., \& Franklin, G. A. (1982). Bureaucracy and policy implementation. Homewood, Illinois: The Dorsey Press.
Sabatier, P. (1986). Top-down and bottom-up approaches to implementation research: A critical analysis and suggested synthesis. Journal of Public Policy, 6(1), 2148.

Sabatier, P., \& Mazmanian, D. (1980). The implementation of public policy: A framework of analysis. Policy Studies Journal, 8(4), 538-560.

Skjærseth, J. B., \& Wettestad, J. (2008). Implementing EU emissions trading: Success or failure? International Environmental Agreements, 8(3), 275-290.

The Guardian. (2015, February 18). Surge in number of migrants trying to reach Italy from Libya. The Guardian. Retrieved from http://www.theguardian.com/ world/2015/feb/18/thousands-of-migrants-nearlydie-in-a-week-trying-to-reach-italy-from-libya

Treib, O. (2006). Implementing and complying with EU governance outputs. Living Reviews in European Governance, 1(1).

Van Meter, D. S., \& Van Horn, C. E. (1975). The policy implementation process. A conceptual framework. Administration \& Society, 6(4), 445-488.

Van Selm, J. (2005). Where migration policy is made: Starting to expose the labyrinth of national institutional settings for migration policy making and implementation. Geneva: Global Commission on International Migration.

Weinar, A. (2011). EU cooperation challenges in external migration policy. Florence: Robert Schuman Centre for Advanced Studies.

Wunderlich, D. (2012). The limits of external governance: Implementing EU external migration policy. Journal of European Public Policy, 19(9), 1414-1433.

Wunderlich, D. (2013a). Implementing EU external migration policy: Security-driven by default? Comparative European Politics, 11(4), 406-427.

Wunderlich, D. (2013b). Towards coherence of EU external migration policy? Implementing a complex policy. International Migration, 51(6), 21-40.

\section{About the Author}

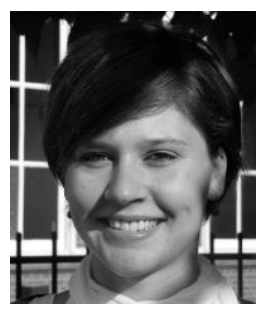

\section{Dr. Natasja Reslow}

Natasja Reslow is a post-doctoral researcher at the Faculty of Law, Maastricht University. Her main research interest is in the external dimension of EU migration policy, and the results of her research have been published in the Journal of Common Market Studies, the European Journal of Migration and Law, and the European Foreign Affairs Review. Currently she is working on the FP7 project "EURA-net", concerning temporary migration between Europe and Asia. 